\title{
Kepuasan Perawat Bagian Poliklinik Terhadap Pelayanan Rekam Medis Rawat Jalan di Rumah Sakit Tk.II 04.05.01 Dr. Soedjono Magelang
}

\author{
Ahmad Farizaan ${ }^{1}$, Rawi Miharti ${ }^{2}$ \\ Diploma III Rekam Medis Sekolah Vokasi Universitas Gadjah Mada ${ }^{1,2}$ \\ ahmad.farizaan@mail.ugm.ac.id, r4wimiharti@gmail.com
}

\begin{abstract}
ABSTRAK
Latar Belakang: Berkas rekam medis dituntut tersedia tepat waktu untuk digunakan oleh dokter dan perawat. Dokter dan perawat berkolaborasi sebagai pembuat informasi kesehatan yang nantinya akan didokumentasikan didalam rekam medis sebagai bukti pelayanan. Berdasarkan observasi, petugas rekam medis dalam memberikan pelayanan rekam medis rawat jalan dinilai belum maksimal, dan terdapat beberapa masalah, seperti proses pelayanan yang lama sehingga mengalami keterlambatan penyediaan rekam medis ke poliklinik.

Tujuan penelitian: mengetahui tingkat kepuasan perawat poliklinik terhadap pelayanan rekam medis rawat jalan Mengetahui gambaran kualitas pelayanan rekam medis rawat jalan. Mengetahui atribut yang perlu diperbaiki terkait pelayanan rekam medis rawat jalan

Metode: Kuantitatif deskriptif dengan pendekatan cross sectional, populasi pada penelitian ini adalah perawat bagian poliklinik, sampel penelitian ini seluruh perawat bagian poliklinik yaitu 45 orang, Teknik pengumpulan data menggunakan kuesioner. Analisis data menggunakan analisis deskriptif, Customer Satisfaction Index, dan Importance performance analysis.

Hasil: Tingkat kepuasan perawat poliklinik terhadap pelayanan berkas rekam medis rawat jalan adalah $79,02 \%$, dapat diartikan puas. Kualitas Pelayanan rekam medis rawat jalan berdasarkan dimensi reliability memiliki nilai rata-rata 3,09, responsiveness adalah 3,18, assurance adalah 3,13, emphaty adalah 3,22, dan tangible adalah 3,23. Atribut yang perlu diperbaiki terkait pelayanan rekam medis rawat jalan adalah ketepatan waktu, kecepatan dan ketepatan dalam memberikan pelayanan.

Kesimpulan: Perawat puas terhadap pelayanan rekam medis rawat jalan. Nilai rata-rata kualitas pelayanan tertinggi pada dimensi tangible, sedangkan nilai rata-rata yang terendah pada dimensi reliability. Atribut yang perlu diperbaiki terkait pelayanan rekam medis rawat jalan adalah ketepatan waktu, kecepatan dan ketepatan dalam memberikan pelayanan.
\end{abstract}

Kata Kunci: Kepuasan Perawat, Pelayanan Rekam Medis, Customer Satisfaction Index, Importance performance analysis

\begin{abstract}
Background: File medical records required are available in time to be used by doctors and nurses. Doctors and nurses collaborate as a maker of health information that will be documented in the medical record as proof of service. Based on the observation of medical records clerk in providing outpatient medical record service maximum rated yet, and there are some problems, such as long service process that delayed the provision of medical records to the clinic.

Objective: to know the level of satisfaction of nurses clinic against medical records of outpatient services based methods Customer Satisfaction Index. Determine the picture quality of outpatient medical record service. Knowing the attributes that need to be corrected associated outpatient medical record service based methods Importance performance analysis.

Methods: Quantitative Descriptive and cross sectional approach, the population in this study are part of the clinic nurse, nurse research sample of this entire section polyclinic ie 45 people, data collection technique using a questionnaire. Analysis of data using descriptive analysis, Customer Satisfaction Index, and the Importance of performance analysis.

Results: The level of satisfaction with the services the clinic nurse outpatient medical record file is $79.02 \%$, can be interpreted satisfied. Quality Service outpatient medical record based on reliability dimension has an average value of 3.09, responsiveness is 3.18, assurance is 3.13, empathy is 3.22, and tangible is 3,23, Thus it can be seen that the average value of the highest quality on tangible dimension, while the average value of the lowest in reliability dimension. The attributes that need to be corrected associated services outpatient medical record file based method Importance of performance analysis is the timeliness in providing services, and the speed and accuracy in providing services.
\end{abstract}

Keywords: Satisfaction of Nurses, Medical Record Services, Customer Satisfaction Index, Importance performance analysis 


\section{PENDAHULUAN}

\section{A. Latar Belakang}

Menurut Peraturan Menteri Kesehatan Republik Indonesia No.269 /Menkes /Per /III/2008 tentang Rekam Medis pada Pasal 5 menyebutkan bahwa setiap dokter dalam menjalankan praktiknya harus membuat rekam medis. Dokter dan perawat berkolaborasi sebagai pembuat informasi kesehatan yang nantinya akan didokumentasikan di dalam rekam medis sebagai bukti pelayanan. Pendokumentasian informasi kesehatan berguna dalam hal melindungi kerahasiaan pasien dan bukti penelitian. Rekam medis juga menyediakan data yang dapat melindungi kepentingan hukum pasien dalam kasus-kasus kecelakaan pribadi atau malpraktik. Bagi penyedia layanan kesehatan rekam medis menyediakan informasi untuk membantu seluruh tenaga kesehatan dalam merawat pasien selama pasien dirawat dirumah sakit, dan pada kunjungan berikutnya. Rekam medis membatu dokter dalam menyediakan perawatan berkesinambungan.

Berdasarkan hasil pengamatan dan observasi di Rumah Sakit TK. II 04.05.01 Dr Soedjono Magelang, peneliti memperoleh beberapa masalah terkait pelayanan rekam medis rawat jalan. Terjadinya keterlambatan penyediaan berkas rekam medis rawat jalan. Hal ini diperkuat oleh penelitian yang dilakukan oleh Fatimah (2015) rata-rata penyediaan rekam medis rawat jalan di Rumah Sakit TK. II 04.05.01 Dr Soedjono Magelang adalah 44,34 menit.

Berkas rekam medis yang lama tidak berada di poliklinik, dokter menuliskan hasil pemeriksaan pasien pada lembar rawat jalan yang baru. Formulir rawat jalan tersebut akan dimasukkan ke map rekam medis, apabila rekam medis sudah sampai dipoliklinik. Formulir rawat jalan yang terpisah menyebabkan rekam medis pasien tidak tersusun secara kronologis. Permasalahan lain terkait pelayanan rekam medis rawat jalan adalah berkas rekam medis yang belum kembali dari bangsal perawatan. Petugas rekam medis harus mencari ke bangsal. Pencarian berkas rekam medis ke bangsal perawatan akan menghambat pelayanan penyediaan berkas rekam medis rawat jalan.
Berdasarkan hasil penelitian yang dilakukan oleh Fatimah (2015) bahwa petugas filing mengetahui dengan baik tentang rekam medis dan tempat penyimpanan. Petugas filing belum mengetahui dengan baik tentang sistem dan metode penyimpanan, Standar pelayanan minimal tentang waktu penyediaan rekam medis rawat jalan. Latar belakang pendidikan petugas filing belum sesuai dengan kualifikasi pendidikan menurut Permenkes Nomor 55 Tahun 2013 tentang Penyelenggaraan Pekerjaan Perekam Medis. Satu dari lima petugas filing pernah mengikuti pelatihan rekam medis tetapi dalam bentuk seminar rekam medis. Pengalaman kerja petugas filing di rumah sakir TK. II 04.05.01 dr. Soedjono Magelang adalah $<1$ tahun (40\%), $1-5$ tahun (40\%), dan 6-10 tahun (20\%).

Melihat pentingnya ketersediaan rekam medis untuk pendokumentasian pelayanan medis yang diberikan dokter dan perawat, dan beberapa masalah terkait pelayanan rekam medis rawat jalan yang dapat diartikan sebagai kualitas pelayanan yang akan mempengaruhi kepuasan seseorang. Peneliti ingin mengambil judul penelitian "Analisis Kepuasan Perawat bagian Poliklinik terhadap Pelayanan Rekam Medis Rawat Jalan di Rumah Sakit TK. II 04.05.01 Dr Soedjono Magelang.

B. Tinjauan Pustaka

1. Menurut Zeithaml dkk dalam Hardiyansyah (2011) kualitas pelayanan dapat dinilai berdasarkan 5 dimensi, yaitu berwujud (tangible), kehandalan (reliability), ketanggapan (responsiveness), empati (emphaty), dan keyakinan (assurance).

2. Importance performance analysis (IPA)

Menurut Tjiptono (2005) teknik importance performance analysis dikembangkan oleh Martilla dan James pada tahun 1977 dalam artikel "Importance performance analysis" yang mereka publikasikan di Journal of Marketing. Rumus untuk mengukur rata-rata tingkat kinerja dan tingkat kepentingan pada setiap atribut kualitas pelayanan rekam medis rawat jalan adalah:

$$
\bar{X}=\frac{\sum x i}{n} \bar{Y}=\frac{\sum y i}{n}
$$


Kepuasan Perawat Bagian Poliklinik Terhadap Pelayanan Rekam ....

Keterangan:

$\mathrm{Xi}=$ Rata-rata dari rata-rata skor tingkat kinerja seluruh atribut

$\mathrm{Yi}=$ Rata dari rata-rata skor tingkat kepentingan seluruh atribut

$\bar{X}=$ Skor rata-rata nilai kinerja pelayanan

$\bar{Y}=$ Skor rata-rata tingkat kepentingan

$\mathrm{n}=$ Jumlah responden

Output dari analisis ini adalah berupa diagram kartesius, yaitu sebagai berikut:

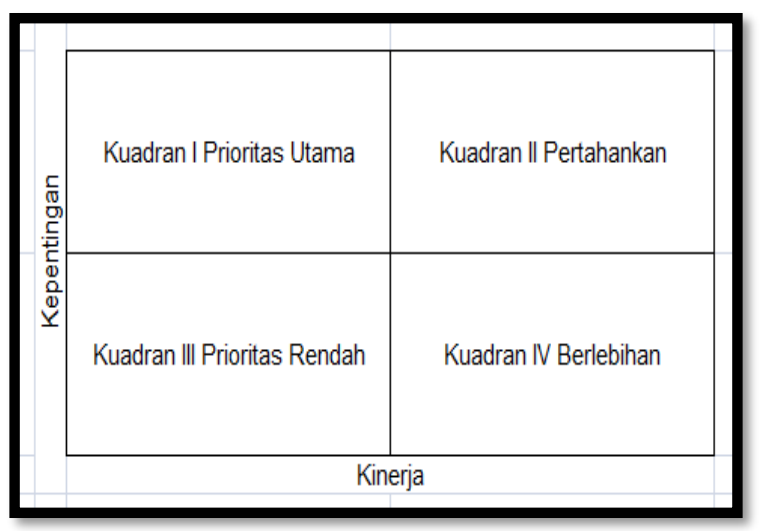

Gambar 1. Diagram Kartesius Sumber: Tjiptono (2005)

Kuadran I : Atribut yang masuk pada bagian kuadran I dianggap mempengaruhi kepuasan, termasuk unsur-unsur jasa yang dianggap sangat penting, namun manajmen belum melaksanakannya sesuai keinginan penerima pelayanan, sehingga mengecewakan/tidak puas. Atribut yang masuk kuadran I harus segera ditingkatkan kinerjanya.

Kuadran II : Atribut yang masuk pada bagian kuadran II dianggap telah berhasil dilaksanakan perusahaa, untuk itu wajib dipertahankannya, dianggap sangat penting dan sangat memuaskan.

Kuadran III : Atribut yang masuk pada bagian kuadran III kurang penting pengaruhnya bagi penerima pelayanan, pelaksanaannya oleh perusahaan biasa-biasa saja, dianggap kurang penting dan kurang memuaskan.

Kuadran IV : Atribut yang masuk pada bagian kuadran IV menunjukkan faktor yang mempengaruhi pelanggan kurang penting, akan tetapi pelaksanaanya berlebihan,dianggap kurang penting tetapi sangat memuaskan.

\section{Customer Satisfaction Index}

Menurut Pohandry dkk. (2013) Customer Satisfaction Index (CSI) adalah analisis yang menggambarkan persentase penggunaan yang senang dengan suatu surve i kepuasan pelanggan. Proses perhitungan dapat diilustrasikan pada tabel berikut ini:

Tabel 1. Ilustrasi perhitungan Customer Satisfaction Index (CSI)

\begin{tabular}{|c|c|c|c|}
\hline \multirow[t]{2}{*}{ Atribut } & $\begin{array}{l}\text { Kepentingan } \\
\text { (I) }\end{array}$ & $\begin{array}{l}\text { Kinerja } \\
(\mathrm{P})\end{array}$ & Skor (S) \\
\hline & Skala (1-4) & $\begin{array}{l}\text { Skala (1- } \\
\text { 4) }\end{array}$ & $\begin{array}{c}(\mathrm{S})=(\mathrm{I}) \mathrm{x} \\
(\mathrm{P})\end{array}$ \\
\hline$\ldots$ & $\ldots$ & $\ldots$ & \\
\hline Total & Total $(\mathrm{I})=(\mathrm{Y})$ & & $\begin{array}{l}\text { Total }(\mathrm{S})= \\
(\mathrm{T})\end{array}$ \\
\hline
\end{tabular}

Sumber: Pohandry dkk. (2013)

Nilai rata-rata pada kolom kepentingan (I) dijumlahkan sehingga diperoleh $\mathrm{Y}$ dan juga hasil kali I dengan P pada kolom skor (S) dijumlahkan dan diperoleh T. CSI diperoleh dari perhitungan $(\mathrm{T} / 4 \mathrm{Y}) \times 100 \%$. Nilai 4 (pada 4Y) adalah nilai maksimum yang digunakan pada skala pengukuran. CSI dihitung dengan rumus

$$
C S I=\frac{T}{x . Y} \times 100 \%
$$

Menurut Ihshani dalam Susan (2014) hasil dari penghitungan kepuasan dengan rumus CSI, dapat ditarik kesimpulan/diintepretasikan. Berikut adalah intrepetasi dari nilai CSI: 
Kepuasan Perawat Bagian Poliklinik Terhadap Pelayanan Rekam ....

Tabel 2. Interpretasi Customer Satisfaction Index

\begin{tabular}{cc}
\hline Angka Index & Interpetasi \\
\hline $0,00-0,34$ & Tidak Puas \\
$0,35-0,50$ & Kurang Puas \\
$0,51-0,65$ & Cukup Puas \\
$0,66-0,80$ & Puas \\
$0,81-1,00$ & Sangat Puas \\
\hline
\end{tabular}

Sumber: Ihshani dalam Susan (2014)

\section{METODE}

Desain penelitian kuantitatif deskriptif dengan pendekatan cross sectional, populasi pada penelitian ini adalah perawat bagian poliklinik, sampel penelitian ini seluruh perawat bagian poliklinik yaitu 45 orang. Teknik pengumpulan data menggunakan kuesioner. Teknik analisis yang digunakan adalah Analisis Deskriptif, mportance performance analysis (IPA), Customer Satisfaction Index (CSI).

\section{HASIL DAN PEMBAHASAN}

1. Tingkat Kepuasan Perawat Poliklinik Terhadap Pelayanan Rekam Medis Rawat Jalan Berdasarkan Metode Customer Satisfaction Index

Berdasarkan hasil pengolahan data dari penyebaran kuesioner kepada 45 perawat bagian poliklinik di Rumah Sakit TK. II 04.05.01 Dr. Soedjono Magelang, diperoleh data untuk mempermudah perhitungan tingkat kepuasan perawat bagian poliklinik terhadap pelayanan rekam medis rawat jalan, yang disajikan pada tabel 3 berikut ini:

Tabel 3. Perhitungan Customer Satisfaction Index

\begin{tabular}{|c|c|c|c|c|c|}
\hline No & Pernyataan & Kepentingan (I) & Kinerja $(\mathrm{P})$ & $\begin{array}{l}\text { Skor } \\
\text { (S) }\end{array}$ & GAP \\
\hline 1 & ketepatan waktu & 3,71 & 3,02 & 11,22 & $-0,689$ \\
\hline 2 & $\begin{array}{l}\text { Memberikan pelayanan sesuai janji } \\
\text { yang diberikan }\end{array}$ & 3,51 & 3,09 & 10,85 & $-0,422$ \\
\hline 3 & Tanggung jawab setiap ada masalah & 3,49 & 3,22 & 11,24 & $-0,267$ \\
\hline 4 & $\begin{array}{l}\text { Memberikan informasi tentang kapan } \\
\text { pelayanan akan terealisasi. }\end{array}$ & 3,44 & 3,02 & 10,41 & $-0,422$ \\
\hline 5 & $\begin{array}{l}\text { Siap dalam membantu mencarikan } \\
\text { berkas rekam medis saat diperlukan }\end{array}$ & 3,67 & 3,27 & 11,98 & $-0,400$ \\
\hline 6 & $\begin{array}{l}\text { Ketanggap apabila ada berkas rekam } \\
\text { medis yang belum tersedia }\end{array}$ & 3,56 & 3,22 & 11,46 & $-0,333$ \\
\hline 7 & $\begin{array}{l}\text { Berupaya dalam } \\
\text { menyelesaikan masalah }\end{array}$ & 3,60 & 3,22 & 11,60 & $-0,378$ \\
\hline 8 & $\begin{array}{l}\text { Cepat dan tepat dalam memberikan } \\
\text { pelayanan }\end{array}$ & 3,67 & 3,02 & 11,08 & $-0,644$ \\
\hline 9 & $\begin{array}{l}\text { Kemampuan petugas rekam medis } \\
\text { setiap melakukan pelayanan }\end{array}$ & 3,47 & 3,09 & 10,71 & $-0,378$ \\
\hline 10 & $\begin{array}{l}\text { Dapat dipercaya setiap melakukan } \\
\text { pelayanan }\end{array}$ & 3,49 & 3,11 & 10,85 & $-0,378$ \\
\hline 11 & $\begin{array}{l}\text { Memberikan pelayanan dengan sopan, } \\
\text { santun, dan professional. }\end{array}$ & 3,58 & 3,31 & 11,85 & $-0,267$ \\
\hline 12 & $\begin{array}{l}\text { Tidak membiarkan menunggu tanpa } \\
\text { kejelasan }\end{array}$ & 3,49 & 3,00 & 10,47 & $-0,489$ \\
\hline 13 & Adanya komunikasi yang baik & 3,49 & 3,27 & 11,40 & $-0,222$ \\
\hline 14 & $\begin{array}{l}\text { Memberikan perhatian kepada anda, } \\
\text { dalam memberikan pelayanan }\end{array}$ & 3,53 & 3,18 & 11,23 & $-0,356$ \\
\hline 15 & $\begin{array}{l}\text { Berpenampilan rapi, sesuai dengan } \\
\text { seragam yang ditentukan rumah sakit. }\end{array}$ & 3,51 & 3,31 & 11,63 & $-0,200$ \\
\hline 16 & $\begin{array}{l}\text { Kemudahan akses dalam permohonan } \\
\text { pelayanan }\end{array}$ & 3,51 & 3,20 & 11,24 & $-0,311$ \\
\hline 17 & $\begin{array}{l}\text { Petugas selalu ada ditempat saat } \\
\text { dibutuhkan }\end{array}$ & 3,56 & 3,18 & 11,30 & $-0,378$ \\
\hline \multicolumn{2}{|r|}{ TOTAL } & 60,27 & 53,73 & 190,49 & $-6,533$ \\
\hline
\end{tabular}


Nilai skor (S) adalah hasil perkalian antara nilai rata-rata tingkat kepentingan (I) dan nilai kinerja (P). Nilai total pada kolom kepentingan (I) diperoleh angka 60,29 sebagai nilai $Y$ pada rumus CSI. Nilai total pada kolom skor (S) diperoleh angka 190,56 sebagai nilai $\mathrm{T}$ pada rumus CSI. CSI diperoleh berdasarkan rumus (T/4Y) x 100\%. Nilai 4 pada $4 \mathrm{Y}$ adalah nilai maksimal yang digunakan pada skala pengukuran penelitian ini. Berikut adalah perhitungan tingkat kepuasan perawat bagian poliklinik terhadap pelayanan rekam medis rawat jalan:

$$
\begin{array}{r}
\mathrm{CSI}=\frac{\mathrm{T}}{\mathrm{XxY}} \times 100 \% \\
\mathrm{CSI}=\frac{190,56}{4 \times 60,29} \times 100 \%
\end{array}
$$

$$
\mathrm{CSI}=79,02 \%
$$

Nilai kepuasan sebesar 79,02\% diartikan bahwa perawat poliklinik puas terhadap pelayanan rekam medis rawat jalan.

\section{Gambaran Kualitas Pelayanan Rekam Medis Rawan Jalan}

Berikut adalah diagram batang yang dapat menggambarkan kualitas pelayanan berdasarkan lima dimensi kualitas pelayanan:

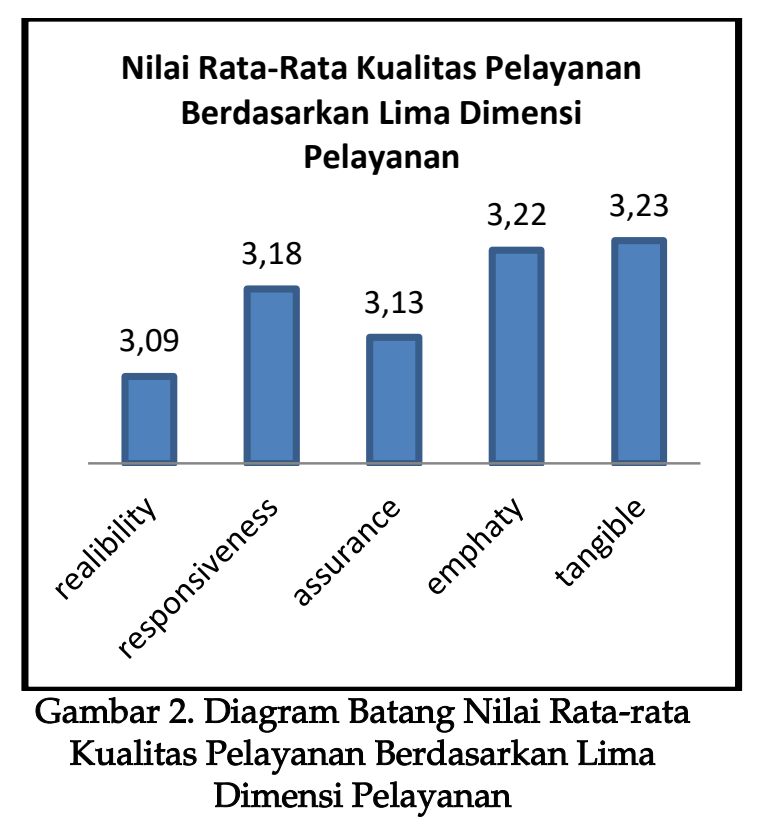

Berdasarkan analisis statistik pada nilai rata-rata tiap dimensi kualitas pelayanan rekam medis, diperoleh nilai rata-rata berdasarkan lima dimensi. Nilai rata-rata kualitas pelayanan paling tinggi adalah pada dimensi tangible, sedangkan nilai rata-rata kualitas pelayanan pada dimensi reliability memiliki nilai rata-rata yang paling rendah jika dibandingkan dengan nilai rata-rata pada dimensi kualitas pelayanan yang lain. Menurut Parasuraman et al dalam Pangastuti (2007) dimensi reliability merupakan dimensi yang memiliki pengaruh besar dan berkontribusi secara langsung terhadap kepuasan. Teori ini dibuktikan dengan hasil penelitian yang dilakukan oleh Mare (2002), Carman (1990), dan Noor (2002), yang dimuat dalam Pangastuti (2007) bahwa dimensi reliability berpengaruh secara positif dan signifikan terhadap kepuasan. Menurut Irawan (2009) untuk meningkatkan kualitas pelayanan pada dimensi reliability organiasasi pemberi pelayanan harus melakukan beberapa hal berikut:

a. Membentuk budaya kerja yang "error free" yang artinya meminimalkan kesalahan dalam melakukan pelayana

b. Adanya insfrastruktur yang memadai dalam memberikan pelayanan. hal ini dapat dilakukan dengan cara memberikan pelatihan secara terus menerus dan menekankan budaya kerja tim atau team work yang baik

c. Menguji terlebih dahulu sebelum suatu pelayanan dilakukan atau dikerjakan

3. Atribut yang perlu diperbaiki terkait pelayanan rekam medis rawat jalan, berdasarkan metode Importance performance analysis

Perhitungan dilakukan dengan melihat nilai rata-rata tingkat kepentingan sebagai sumbu $(Y)$ dan tingkat kinerja sebagai sumbu (X). Berikut adalah tabel nilai rata-rata dari setiap atribut.

Kedua nilai tersebut yaitu nilai kepentingan dan nilai kinerja digabungkan dan disajikan dalam 
diagram kartesius. Cara untuk menggabungkan kedua nilai kepentingan dan nilai kinerja dengan menggunakan Microsoft Excel. Secara manual dapat dideskripsikan sebagai berikut:

1. Nilai kinerja menjadi sumbu $X$, sedangkan nilai kepentingan menjadi sumbu $Y$;

2. Lengkapi sumbu $X$ dan sumbu $Y$ dengan nilai rata-rata setiap kolom;

3. Kemudian mencari koordinat atau titik potong antara kedua nilai tersebut, untuk setiap atribut penilaian. Dengan cara menarik garis lurus nilai rata rata atribut kinerja secara vertical sedangkan nilai ratarata tingkat kinerja secara horizontal, sehingga diperoleh titik potong antara nilai kinerja dan nilai kepentingan untuk setiap atribut;

4. Nilai rata-rata (mean) dari nilai ratarata tingkat kepentingan dan tingkat kinerja digunakan sebagai garis tengah yang membagi diagram kartesius menjadi empat kuadran, sehingga menghasilkan kelompok daerah yang berbeda.

Diagram kartesius dapat dilihat dibawah ini:

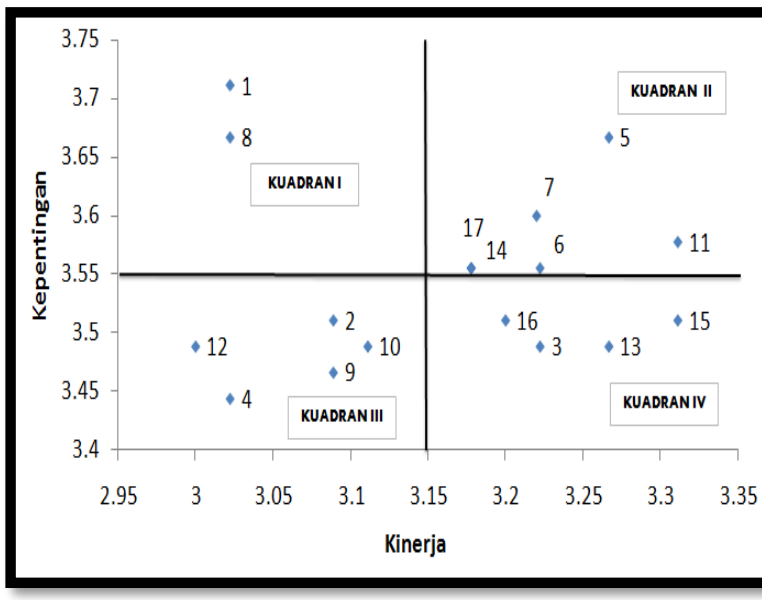

Gambar 3. Diagram Kartesius Hasil Perhitungan Menggunakan Metode Importance performance analysis

Menurut Tjiptono (2005) atribut yang masuk pada bagian kuadran I dianggap mempengaruhi kepuasan, termasuk unsur-unsur jasa yang dianggap sangat penting, namun manajmen belum melaksanakannya sesuai keinginan penerima pelayanan, sehingga mengecewakan/tidak puas. Atribut pelayanan rekam medis yang masuk pada kuadran I adalah:

1) ketepatan waktu

2) kecepatan dan ketepatan dalam memberikan pelayanan

Kedua atribut tersebut masuk pada kuadran I, sehingga dapat disimpulkan, berdasarkan hasil yang diperoleh dari analisis data diatas meunjukkan bahwa faktor-faktor yang penting dalam pelayanan rekam medis rawat jalan terhadap kepuasan perawat adalah ketepatan waktu, dan kecepatan dalam memberikan pelayanan. Kedua atribut tersebut berorientasi pada waktu, sehingga dalam memberikan pelayanan rekam medis rawat jalan orientasi pada ketepatan dan kecepatan waktu sangatlah penting. Kondisi tersebut dapat digunakan sebagai tolak ukur dalam upaya memperbaiki pelayanan rekam medis rawat jalan, dalam menyikapi kebutuhan rekam medis rawat jalan.

Kecepatan dan ketepatan waktu dalam memberikan pelayanan rekam medis rawat jalan akan menunjukkan pelayanan medis yang baik pula. Menurut Antikasari (2006) lamanya waktu dalam mencari dan menyediakan berkas rekam medis merupakan indikator yang menunjukkan kepuasan pasien disuatu rumah sakit.

\section{PENUTUP}

\section{A. Kesimpulan}

1. Tingkat kepuasan perawat poliklinik terhadap pelayanan berkas rekam medis rawat jalan adalah $79,02 \%$ diartikan bahwa perawat poliklinik puas terhadap pelayanan rekam medis rawat jalan. Index kepuasan belum 79,02\% dikarenakan terdapat kesenjangan (GAP) nilai GAP tertinggi pada atribut ketepatan waktu, yaitu $-0,689$.

2. Berdasarkan dimensi reliability nilai rata-rata kualitas pelayanan adalah 3,09, berdasarkan dimensi responsiveness adalah 3,18, berdasarkan dimensi assurance adalah 3,13, berdasarkan dimensi 
emphaty adalah 3,22, dan berdasarkan dimensi tangible adalah 3,23. Dengan demikian dapat diketahui bahwa nilai rata-rata kualitas pelayanan tertinggi pada dimensi tangible, sedangkan nilai rata-rata yang terendah pada dimensi reliability.

3. Atribut yang perlu diperbaiki terkait pelayanan berkas rekam medis rawat jalan berdasarkan metode Importance performance analysis adalah ketepatan waktu, dan kecepatan dan ketepatan dalam memberikan pelayanan.

\section{B. Saran}

1. Meningkatkan kecepatan pelayanan, sehingga dapat mempengaruhi ketepatan waktu dalam menyediakan berkas rekam medis rawat jalan dengan cara menyelesaikan masalah yang menghambat pelayanan rekam medis rawat jalan, seperti:

a. keterlambatan pengembalian berkas rekam medis rawat inap sehingga petugas tidak harus ke bangsal untuk mencari berkas rekam medis.

b. mempercepat pengolahan data (bagian analisa dan coding) agar berkas rekam medis selalu ada di rak penyimpanan.

2. Dimensi reliability menjadi dimensi dengan nilai paling rendah diantara dimensi pelayanan yang lain sehingga perlu ditingkatkan lagi dengan cara membentuk budaya kerja yang "error free" yang artinya meminimalkan kesalahan saat melakukan pelayanan rekam medis rawat jalan, memberikan pelatihan kepada petugas filing tentang sistem penyimpanan, dan pelayanan rekam medis, dan menekankan budaya kerja tim atau team work yang baik pada petugas bagian filing.

3. Unit rekam medis di Rumah Sakit TK.II.04.05.01 Dr. Soedjono Magelang sebaiknya membuat standar ketepatan waktu dan kecepatan pelayanan rekam medis rawat jalan, agar ada hak dan kewajiban petugas rekam medis yang harus dipenuhi dalam memberikan pelayanan rekam medis rawat jalan.

\section{DAFTAR PUSTAKA}

Antikasari. (2006). Waktu Pendistribusian Berkas Rekam Medis Pasien Lama Ke Poliklinik Bedah RS Umum Pusat Dr. Sardjito Yogyakarta (Tidak dipublikasikan). Tugas Akhir. Yogyakarta: Diploma III Rekam Medis, Sekolah Vokasi, Universitas Gadjah Mada.

Depkes RI. (2008). Peraturan Menteri Kesehatan Republik Indonesia No.269/Menkes/Per/III/2008

tentang Rekam Medis. www.hukor.depkes.go.id. Diakses tanggal 15 Desember 2015.

Fatimah, N. (2015). Analisis Kemampuan Petugas Filing dalam Menyediakan Rekam Medis Rawat Jalan klinik Interna di RST dr. Soedjono Magelang (tidak dipublikasikan). Tugas Akhir. Yogyakarta: Diploma III Rekam Medis, Sekolah Vokasi, Universitas Gadjah Mada.

Hardiyansyah. (2011). Kualitas Pelayanan Publik Konsep, Dimensi, Indikator, dan Implementasinya. Yogyakarta: Gava Media.

Irawan, H. (2009). 10 Prinsip Kepuasan Pelanggan.Jakarta: PT Elex Media Komputindo Kelompok Gramedia.

Tjiptono, F. (2005). Service, Quality \& Satisfaction, Edisi 1. Yogyakarta: Andi.Umar,

Pohandry, A., Sidarto., Winarni. (2013). Analisis Tingkat Kepuasan Pelanggan Dengan Menggunakan Metode Customer Satisfaction Index dan Importance performance analysis Serta Service Quality. Jurnal REKA VASI. 1 (1): 21-29.

Susan, E.F. (2014). Analisis Pengaruh Kualitas Pelayanan Terhadapa Kepuasan Pelanggan Air MInum Tahun 2013 (Studi Pada PDAM Sleman) (tidak dipublikasikan). Skripsi. Yogyakarta: S2 Magister Ekonomi Pembangunan, Universitas Gadjah Mada. 
Kepuasan Perawat Bagian Poliklinik Terhadap Pelayanan Rekam ....

Pangastuti, N.Y. (2007). Pengaruh Dimensi

Kualitas Jasa Yang Meliputi

Tangible, Reliability,

Responsiveness, Assuranse, dan

Empaty Pada Kepuasan Konsumen

(Tidak dipublikasikan). Tesis.

Yogyakarta: Program Magister

Manajemen, Sekolah Pascasarjana,

Universitas Gadjah Mada. 